\title{
Fostering Creativity in Engineering Universities: Research Activity and Curriculum Policy
}

\author{
Anatoly V. Kozlov \\ Corresponding author, Branch of Tyumen Industrial University in Noyabrsk, Russia, \\ anatoly_kozlov@yahoo.com
}

\section{Svetlana A. Shemshurina}

Branch of Tyumen Industrial University in Noyabrsk, Russia

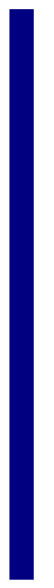

Supplying students with a good understanding of research activity tools is one of the challenges in modern technical education. The aim of this study is to develop a multipurpose technological support for shaping creative activity of students in engineering universities. The research included a survey of 150 students in the age of 18-22 majoring in Technology of Transport Processes for 1-5 years. Engineering student's research competency levels were examined at the preliminary stage. A system that allows building a general strategy of designing student's research activity within the system of higher education was developed. Professionally-oriented interdisciplinary relationships used to identify the structural elements of a relationship between objects make it possible to realize the unity of common learning goals, to make the process of learning more integral and logical. Mathematical data processing confirmed the efficiency of developed approaches. Methodology of top-level engineer's research competence and creativity formation can be useful to develop optimal curricula for engineering specialties.

Keywords: creative activity, engineering students, creative engineering design, motivational and cognitive components, automotive specialist's preparation

\section{INTRODUCTION}

The postindustrial stage of society development is characterized by the new plants emerging and the outdated ones developing based on the latest achievements in science and technology, and this makes engineers' training more complicated (Rugarcia et al., 2000; Monteiro, Leite \& Rocha, 2018). In this environment, modern automotive manufacture requires highly competent and broad-minded specialists ready to carry out complex scientific research work (Si et al., 2013; Hoidn \& Kärkkäinen, 2014). Their high creative potential should be realized in creative thinking when solving complex engineering problems in an increasingly complicated information environment (Nguyen

Citation: Kozlov, A. V., \& Shemshurina, S. A. (2018). Fostering Creativity in Engineering Universities: Research Activity and Curriculum Policy. International Journal of Instruction, 11(4), 93106. https://doi.org/10.12973/iji.2018.1147a 
\& Shanks, 2009; Wei et al., 2015; Daly, Mosyjowski \& Seifert, 2014). Thus, there has to be an automotive specialist's engineering creativity shaped next to the research creative activity (Baillie, 2002; Cropley, 2016). In this context, creative competence has become relevant and a cross-curricular component in the engineering studies, as educational establishments have to respond to society demands of creative skills profiles (Saorín et al., 2017; Phelan, 2001).

The shift to a qualitative explanation for engineering creativity was aided by the fact that a scientific foundation linking creativity, engineering and technology has already existed (Morse, Babcock \& Murthy, 2014; Blicblau \& Steiner, 1998). It was assumed that human intelligence should be understood in a broader sense, including factors such as generating alternatives and finding multiple possibilities (Guilford, 1950; Corebima, Susilo \& Zubaidah, 2017). As some engineers believe they are not creative, this belief does not mean that they cannot be taught to act creatively (Kazerounian \& Foley, 2007). One can note that creativity deals with the generation of effective and innovative problem solutions (Runco, 2014; Schoen, Bowler \& Schilpzand, 2016). Engineering is concerned more specifically with generating technological options (Fan, 2017). With that, successful engineering design must focus on both convergent and divergent thinking. In fact, engineering can be regarded as a process of creative problem solving (Charyton et al., 2011). Students can build the confidence to practise reflection-in-action with a supportive learning environment that does not hinder their creativity (Green, 2001).

Once can note that creativity has been neglected or dismissed as being less important in curriculum (Badran, 2017; Kazerounian \& Foley, 2007). In turn, we share the view that if students are given the exposure, it is possible to develop and hone creativity and innovation skills (Charyton \& Merrill, 2009).

The process of fostering creativity thinking in engineering universities can be regarded as an integrated approach to solving problems arising after science-intensive technologies are introduced (Cropley \& Cropley, 2005; Daly, Mosyjowski \& Seifert, 2014; Bourgeois-Bougrine et al., 2017). It requires a revision of many approaches towards the solution of pedagogical problems that may arise while designing and implementing integrated engagement systems (Cropley, 2016). These systems require the production and science trends to be taken into consideration, as well as the requirements for automobile industry occupation (Hatchuel, Le Masson \& Weil, 2017). It should be solved by designing and implementing a comprehensive system designed for each student to be involved in scientific work and engineering creativity as part of research work. At this point, teaching creativity will have almost zero impact if it is not immersed in problem solving exercises (Charyton \& Merrill, 2009; Reed, 2011). Therefore, the first step is to revise the style and content of current assignments and in terms of characteristics that stimulate creativity (Chen, Jiang \& Hsu, 2005).

At the present stage, problem-based approach is widely used while preparing engineers, as it involves the process of bringing up problems based on content analysis and reorganization (Brodersen et al., 2016; Kansal, Solanki \& Kansal, 2016). Such approach 
towards interdisciplinary relationships within the system of specialized courses based on a single problem allows introducing wide intercourse relationships not limited to the scope of a topic or course, and affecting knowledge systematization around the core idea taught at the specialized courses based on a single problem (Savery, 2015).

The inter-scientific problem put forward in the course of student's research can be solved by analyzing and comparing data available from different fields of science (Izvorska, 2016). At the same time, its increasing complexity allows raising the level of abstraction and generalization while solving it. This leads to simultaneous development of student's dialectical and systemic thinking.

The purpose of our research is to develop versatile technological support for shaping research creative activity of students in engineering universities. Our innovative teaching system based on the target, content, procedural and organizational aspects was designed to sort out the problem of searching for innovative ways of managing student's educational research and creative activities.

\section{METHOD}

\section{Participants}

Our pedagogical experiment was conducted in 2013-2017 to confirm the hypothesis regarding the efficiency of experimental learning. The experiment was carried out in the November Institute of Oil and Gas (Yamal-Nenets Autonomous District). Of a total of 202 students in the course, the research sample included 150 students in Technology of Transport Processes for 1-5 years in general. The average age of participants was 20 years. Of these students, $71.3 \%$ were males and $28.7 \%$ were females. All the attendees realized the purpose of pedagogical experiment.

\section{Data collection and research techniques}

Research work included two main stages: experimental and control. Thus, to investigate the changes in creativity, we used pre- and post-tests. At processing the results of a pedagogical experiment, the objective was to solve the complex problems of improving the process of controlling and diagnosing the level of student's research competence by rationally using parameter measurements, existing methods and control means that give a quantitative and qualitative picture of the research competency level. At the same time, there was a need in determining the indicators, without which the assessment criteria and methods for diagnosing research competency levels cannot be found. Test data were processed by Microsoft Excel and SPSS Statistics.

The research competence was considered as a training outcome and an indicator of student's readiness to conduct research (Borich, 2016). As for the engineering student's research competence indicators, research work is so specific and complex that the research competency level extremely depends on whether the student is aware of his/her own behavior and peculiarities. It also depends on whether the student is able to search for behavior correction options in accordance with forecasts of personality development. Therefore, engineering student's research activity can be considered as competent only on conditions that personal self-improvement is a dominant motive. 
In terms of management function, control system involves the following operations: diagnosing the research competency level, recording the results and adjusting the upbringing process. In our case, pedagogical control is the process of identifying, measuring and assessing the research competency level of students. Motivational component was studied by questioning while the cognitive component was assessed on the basis of the end-of-course assessments (paper test or an oral questioning); operational component of the research competence was assessed for maturity by comparative analysis of grades and observation results.

Based on the obtained results processed by means of mathematical statistics, this article studies the dynamics of differential research competency level indicators among students of the experimental group. This analysis has confirmed the hypothesis regarding the efficiency of student's study and research modes that allow him/her to be creative continuously, throughout the entire period of specialized course completed with the prevalence of independent (non-standard) research project tasks. Research reliability and scientific validity were achieved due to methodological validity of theoretical positions, developed diagnostic techniques relevant to research objectives, subject and object, as well as due to sample representativeness, quantitative and qualitative data analysis and practical application.

\section{FINDINGS AND DISCUSSION}

Tables 1, 2, and 3 show the engineering student's research competency levels. These levels were determined in students (1-5 grades) based on pedagogical monitoring at an early stage of experiment. Graduates passed an engineering assessment for determining the efficiency of developed system; assessment data were compared with the results of diagnostics (1-5 grades), after which the final result was recorded.

Table1

Engineering student's research competency levels: motivational component

\begin{tabular}{ll}
\hline Level & Characteristics \\
High & $\begin{array}{l}\text { The student is deeply convinced in the need to develop research competence. He/she } \\
\text { is worried about a discrepancy between the research competency level and the } \\
\text { requirements/standards. He/she has a feeling that he/she has to self-improve in the } \\
\text { field of research competence. }\end{array}$ \\
\hline Average & $\begin{array}{l}\text { Student's motivational attitude toward research is formed at the level of cognitive } \\
\text { interest. The student does not show initiative and great independence in self- } \\
\text { improvement in the field of research competence. }\end{array}$ \\
\hline Low & $\begin{array}{l}\text { Student's motivational attitude to research and research competence development is } \\
\text { not formed. }\end{array}$ \\
\hline Table 2 & \\
Engineering student's research competency levels: cognitive component
\end{tabular}


Table 3

Engineering student's research competency levels: operational component

\begin{tabular}{|c|c|c|c|}
\hline $\begin{array}{l}\text { Skills } \\
\text { Level } \\
\end{array}$ & $\begin{array}{l}\text { Investigating, analyzing, predicting } \\
\text { research results }\end{array}$ & $\begin{array}{l}\text { Analyzing own } \\
\text { outcomes }\end{array}$ & Testing \\
\hline High & $\begin{array}{l}\text { The student has to state the } \\
\text { research purpose fully and } \\
\text { clearly, to substantiate and choose } \\
\text { research methods, to develop the } \\
\text { research program correctly and } \\
\text { clearly, to identify the basic } \\
\text { structural components, to } \\
\text { establish the cause-and-effect } \\
\text { relationship between them, to } \\
\text { draw pedagogical conclusions } \\
\text { clearly and fully. The student is } \\
\text { able to predict the results of } \\
\text { pedagogical activity on a } \\
\text { reasonable basis, and to formulate } \\
\text { the hypothesis. }\end{array}$ & $\begin{array}{l}\text { The student } \\
\text { consciously reveals } \\
\text { the reasons for the } \\
\text { difficulties he/she } \\
\text { faces during the } \\
\text { research, and } \\
\text { develops ways to } \\
\text { overcome them. }\end{array}$ & $\begin{array}{l}\text { The student } \\
\text { independently } \\
\text { develops a testing } \\
\text { technique, applies } \\
\text { it and processes the } \\
\text { results. }\end{array}$ \\
\hline Average & $\begin{array}{l}\text { The student does not always state } \\
\text { the research purpose fully and } \\
\text { clearly, choose the research } \\
\text { methods and develop the research } \\
\text { program correctly and clearly. } \\
\text { The student identifies the basic } \\
\text { structural components, but does } \\
\text { not always establish the cause- } \\
\text { and-effect relationship between } \\
\text { them. The student does not } \\
\text { always predict the results or } \\
\text { formulates the hypothesis } \\
\text { accurately. }\end{array}$ & $\begin{array}{l}\text { The teacher helps the } \\
\text { student to find the } \\
\text { reasons for particular } \\
\text { difficulties the student } \\
\text { faces during the } \\
\text { research. The student } \\
\text { is assisted by the } \\
\text { teacher to develop } \\
\text { ways to overcome } \\
\text { these difficulties. }\end{array}$ & $\begin{array}{l}\text { The teacher is } \\
\text { partly involved into } \\
\text { the process of } \\
\text { developing a } \\
\text { testing technique, } \\
\text { its application, as } \\
\text { well as into the } \\
\text { process of } \\
\text { analyzing the } \\
\text { results. }\end{array}$ \\
\hline Low & $\begin{array}{l}\text { The student does not state the } \\
\text { research purpose fully and } \\
\text { clearly. It is difficult for him/her } \\
\text { to choose the research methods } \\
\text { and/or to prepare research } \\
\text { programs. The student } \\
\text { experiences difficulties when it } \\
\text { comes to allocating basic } \\
\text { structural components. The } \\
\text { student does not establish the } \\
\text { cause-and-effect relationship } \\
\text { between the components and } \\
\text { cannot predict the results of } \\
\text { pedagogical activity. }\end{array}$ & $\begin{array}{l}\text { The student realizes } \\
\text { sees no reasons for } \\
\text { own difficulties } \\
\text { during the research. }\end{array}$ & $\begin{array}{l}\text { The student is not } \\
\text { able to develop a } \\
\text { testing technique, } \\
\text { apply it and } \\
\text { process the results } \\
\text { with teacher's } \\
\text { assistance. }\end{array}$ \\
\hline
\end{tabular}

International Journal of Instruction, October $2018 \bullet$ Vol.11, No.4 
After final evaluation, research competency levels of students were high versus the research competency levels of students at the initial stage. A distinctive feature of this level is that the knowledge of students is more systematic, complete and stronger. This is achieved by implementing an integrative approach to designing a system of specialized courses based on a single problem through professionally oriented interdisciplinary relationships.

Test data have shown that problem-based developmental teaching methods used while improving the research work at the engineering university makes it possible to increase the level of motivation among students. As for the problem of improving the system of student's academic and research work (SA\&RW), its analysis shows that the process of considering modern conceptual approaches towards research management involves innovative changes in the system's structure. These changes should be made through the SA\&RW program development and implementation.

Our comprehensive program is a continuous, step-by-step formation of creative abilities and research skills. Thus, there is a need to design and implement the SA\&RW system with such study modes that will allow creatively orienting students throughout the whole period of specialized course completed with the prevalence of independent (nonstandard) research project tasks. The latter could be significantly larger in volume and deeper in content from one complexity level to another. At the same time, it is not developed separately and not in parallel with the existing specialized courses taken by students to form research competence. There should be a phased and system-based line of the same modes throughout the whole period of study.

As a qualitatively new change, the system of specialized courses based on a single problem as an innovative way of organizing SA\&RW. This innovative introduction was made to systemize the specialized courses based on a single problem. This requires a pedagogical research undertaken on a stage basis with successive goals, content, methods and modes at each stage: from learning research methods in practice by finding problems that require a scientific-based solution, finding ways to solve them, managing experiments, and analyzing collected data, making conclusions and recommendations.

This article considers the major trends in specialized course development, establishes their types and requirements for designing a system of special courses based on a single problem. These requirements are the following: scientific background; unity of academic and research work; continuity of topics and content; student-based approach towards student's research activity. In the system of specialized courses based on a single problem, learning technology is bound with the student-based activity approach with an emphasis on interactive learning methods. Automotive specialist's research competence is a result of learning within the system of specialized courses based on a single problem.

Based on theoretical premises, there were defined conceptual teaching provisions for the system of specialized courses called Innovation processes in modern knowledge-based industry (automotive industry case study): system approach; principle of 
interdisciplinary relationships as a system-forming factor of instructional design; interdisciplinary relationship principles interacting with other teaching principles; program-based targeted course renewal; content fixation on continuous personality development, high poly-engineering and creative personality development.

We propose technological support for the system of specialized courses based on a single subject's problem. Professionally-oriented interdisciplinary relationships used to identify the structural elements of a relationship between objects make it possible to realize the unity of common learning goals, to make the process of learning more integral and logical.

Interdisciplinary relationships are a system that includes interrelated functional components: identification, establishment, and implementation of interdisciplinary relationships. Mapping this process required a methodology for selecting the content for specialized courses based on a single problem - Innovation processes in modern knowledge-based industry (automotive industry case study).

The content was selected according to the following methodological principles of content selection: goal compliance principle; problem/content scientific status principle; science-to-program ratio principle; instructional isomorphism principle; content unity principle; potential principle; minimization principle; national/international experience basis principle; content continuity principle. These principles were applied while designing the content for specialized courses (see Table 4). 
Table 4

The system of specialized courses based on a single problem - Innovation processes in modern knowledge-based industry (automotive industry case study)

\section{Specialized course}

Development of metallics used in motor car production in 1990 $-2017$
Students should have an idea about the: main stages of high-quality motor-car body sheet development in Russia;metallics development policy and the creation of AVTOVAZ "allied industries - metal industry" projects; AVTOVAZ cooperation with the metal industry; main trends of creating and developing new types of steels and alloys. Students must know: basic series of alloyed steels to expand parts population; areas of material application, the principles of material classification and labeling in accordance with the existing ones. Students must be able to: address issues related to the choice of material for manufacturing machine parts; formulate and record alloy grades.

Probabilistic static Students should have an idea about the: advanced nature of the course; methods for latest achievements and perspectives in the field of manufacture process analyzing technological processes modeling and analysis by means of probabilistic and static methods. Students must know: basic stages of mathematical modeling; classification of mathematical methods and models; application areas of statistical methods; statistical methods for experimental data processing. Students must be able to: choose probabilistic and static methods for plant process analysis; model and analyze manufacture processes; forecast; test research results.

Boron micro- $\quad$ Students should have an idea about the: cold forging process development alloyed steel towards high-complexity products; boron micro-alloyed steel production as one of introduction; technological and operational properties of $12 \mathrm{GR}$ steel as an the beneficial rolled alternative to $12 \mathrm{KhN} 3 \mathrm{~A}$ steel.

metal saving areas Students must know: requirements for cold forged high-complexity in the machine- $\quad$ products; boron effect on the properties of structural steels; boron microbuilding industry alloyed steel applications.

Students must be able to: determine the effect of boron-containing additives on technological and operational properties of 12 GR steel; compare technological and operational properties of $12 \mathrm{GR}$ steel and $12 \mathrm{KhN} 3$ Asteel; formulate and record boron micro-alloyed steel grades.

Possibility of Using Students should have an idea about the: current manufacture process of 12 GR Boron Steel manufacturing parts (piston pins) made of $12 \mathrm{KhN} 3 \mathrm{~A}$ steel; manufacture instead of 12KhN3A Steel for process features of manufacturing parts (piston pins) made of 12 GR steel;

Manufacturing

Piston Pins for test results.

Motor Vehicles

Students must know: features of thermal (chemico-thermal) treatment of workpieces (piston pins); research methodology: research algorithm, chemical gas analysis (furnace and generator), structural analysis of the workpieces, statistical test procedure, dynamic test procedure, wear test procedure,

Students must be able to analyze: cold forging; machining; chemicothermal treatment; causes of increased wear of parts (piston pins and pistons) during the wear tests.

International Journal of Instruction, October $2018 \bullet$ Vol.11, No.4 


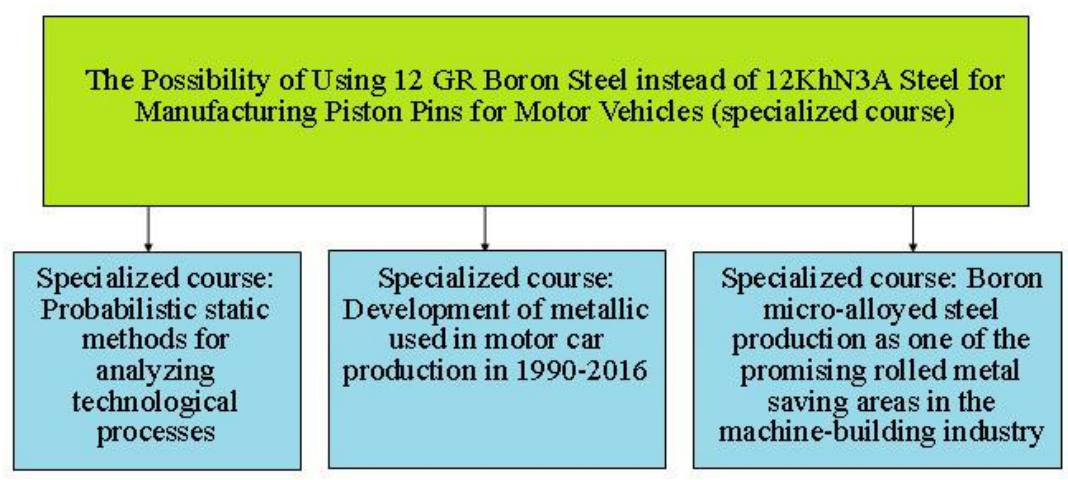

Figure 1

The system of specialized courses based on a single problem - Innovation processes in modern knowledge-based industry (automotive industry case study)

Mapping the professionally-oriented interdisciplinary relationships existing in the system of specialized courses based on a single problem - Innovation processes in modern knowledge-based industry (automotive industry case study) - entails the development of technological support for this system. The content was selected according to the following methodological principles of content selection:

1. Goal compliance principle - learning objectives determine the learning content. However, these objectives can be achieved by means of different content. The common goals of engineering learning were transformed into specific ones in the light of the system of specialized courses based on a single problem.

2. Problem/content scientific status principle - it is unclear what is the required ratio of basic knowledge on the problem and the knowledge that the teacher gives to students. In some cases, this ratio is defined as 1:20. This ratio cannot be the same for all course units, but there is no doubt that the teacher should have a broad scientific outlook on the problem. Thus, there was taken into account the scientific status of the studied problem with a focus on modern boron steel production technologies. The attempt was to reflect them as widely as possible within the framework of our specialized courses.

3. Science-to-program ratio principle - learning content should be based on the latest achievements in the field of rolled steel. However, the problem of relationship between the academic course program and the branch of scientific knowledge cannot be solved by simplifying scientific knowledge for the learner. Thus, there is an original methodological complex introduced with means of instructional communication.

4. Instructional isomorphism principle - basic structural elements and semantic units of the relevant field of science (engineering) are introduced to a course unit after instructional rethinking. In this case, teacher has to preserve the basic elements of the theory and create an environment for these elements to be learned in terms of their nature and relationship between them. The problem of finding teaching equivalents for 
inter-scientific relationships that would correspond to the process of integration in modern knowledge-based industry becomes topical. This happens as there is a need in designing an effective instructional system to improve student's research work through our model of professionally-oriented interdisciplinary relationships.

5. Content unity principle - the content of course units has to be combined for the purpose of learning an integral scientific truth as a basis for research competence formation.

6. Potential principle - specialized courses based on a single problem have to contain units that are important now and those that will be important in the near future, or will be the basis for future studies. Thus, our course has a unit called Basic attractive areas in creating and developing new types of steels and alloys for the automotive industry, which includes the following issues: developing new materials and stabilizing the properties; creating a series of controlled forged microalloyed steels to expand parts population; creating sparingly alloyed steels for transmission parts with improved machining and heat treatment conditions, including nitrogen-doped steels; using boron micro-alloyed steels not only in producing fasteners, but also engines and transmission; developing high-strength steels for bodybuilding; mastering the production of doublesided zinc-ferrum coating for bodybuilding; mastering and expanding the range of tools made of tungstenless steels.

7. Minimization principle - course content should contain the required minimum of information. The increasing volume of information, as well as the changing content in knowledge-based areas of automotive industry, requires careful selection of learning material.

8. National/international experience basis principle is realized by means of comparative analysis of best practices in the field of comparative content assessment in different countries (Babansky, 1989). In this regard, the development of metallics used in motor car production in Russia and abroad was analyzed.

9. Content continuity principle - based on this principle, there were allocated the most significant continuity relationships for The Possibility of Using 12 GR Boron Steel instead of 12KhN3A Steel for Manufacturing Piston Pins for Motor Vehicles course. Based on this list, there was designed the content for the specialized courses based on a single problem - Innovation processes in modern knowledge-based industry (automotive industry case study).

Figure 2 illustrates the content continuity modules required to complete The possibility of manufacturing 12 GR steel parts course unit. 


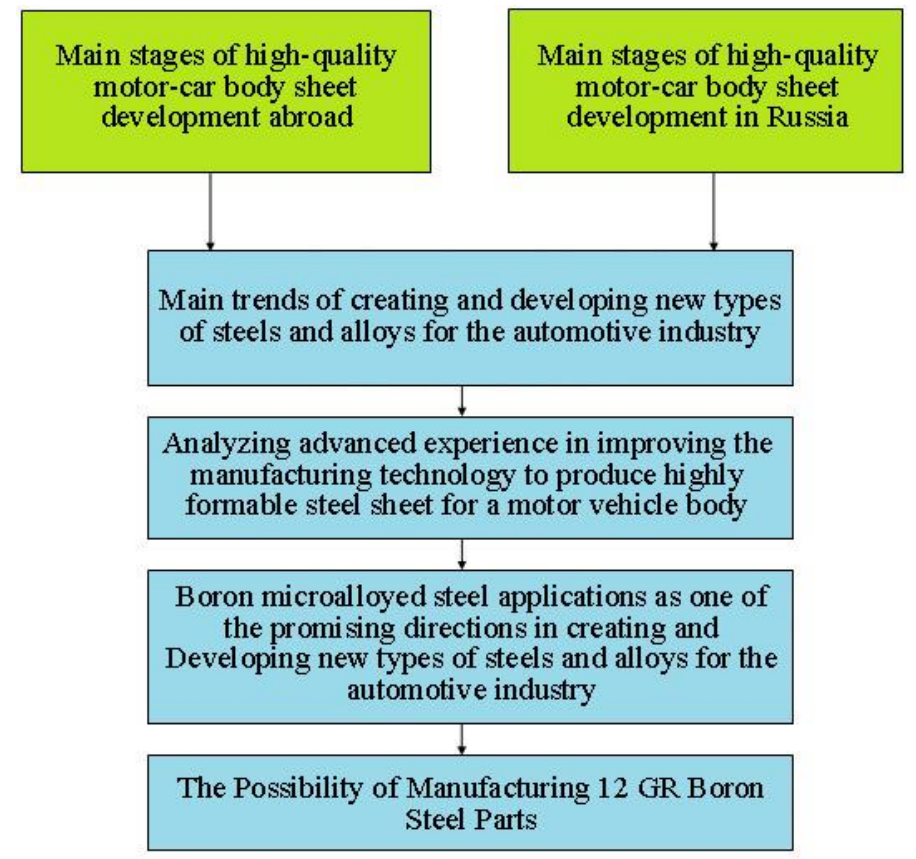

Figure 2

Content continuity modules designed for the system of specialized courses based on a single problem - Innovation processes in modern knowledge-based industry (automotive industry case study)

These principles were applied while designing the content for specialized courses based on a single problem.

It is also important to alternate different forms of students' work (Blythe, Allen \& Powell, 2015). Thus, engineering through means of small groups, brainstorming, and oral presentation in students' projects work reasonable well. An investigation at the Louisiana State University revealed how to use both creative and critical thinking skills while designing a product or solving an open-ended problem (Conwell, Catalano \& Beard, 1993). Tasks offered to the students included a user role-playing exercise, the use of proper brainstorming techniques and problem solving methodologies. As a result, participants were able to design an innovative product. This approach was further approved by Department of Mechanical Engineering at National Central University in Taiwan (Kazerounian \& Foley, 2007).

In general, the concept of creativity contained a number of competence categories that contribute to flexible problem solving in practice that yields creative engineering solutions. Particularly prominent within this cluster is procedural agility. This described the ability to solve problems that are characterized by a multitude of possible pathways to a solution (Walther, Kellam, Sochacka \& Radcliffe, 2011). 


\section{CONCLUSION}

This article introduces a system that allows building a general strategy of designing student's research activity within the system of higher education and developing comprehensive research programs that would include the elements of scientific research by enriching them with research project tasks. The conducted pedagogical experiment has proved the high efficiency of a proposed concept. The chosen integrative approach to academic and research work improvement in the engineering university is supported with experiments. Mathematical data processing confirmed the conclusions made about the efficiency of developed methodological approaches. Our program and methodology of top-level engineer's research competence and creativity formation can be used as a basis for innovation technologies designed to prepare competitive specialists.

\section{REFERENCES}

Badran, I. (2007). Enhancing creativity and innovation in engineering education. European Journal of Engineering Education, 32(5), 573-585.

Baillie, C. (2002). Enhancing creativity in engineering students. Engineering Science Education Journal, 185-192.

Blicblau, A. S., \& Steiner, J. M. (1998). Fostering creativity through engineering projects. European Journal of Engineering Education, 23(1), 55-65.

Blythe, T., Allen, D., \& Powell, B. S. (2015). Looking together at student work. Teachers College Press.

Borich, G. D. (2016). Observation skills for effective teaching: research-based practice. Routledge.

Bourgeois-Bougrine, S., Buisine, S., Vandendriessche, C., Glaveanu, V., \& Lubart, T. (2017). Engineering students' use of creativity and development tools in conceptual product design: What, when and how?. Thinking Skills and Creativity, 24, 104-117.

Brodersen, R. M., Yanoski, D., Hyslop, A. \& Imperatore, C. (2016). Toward the Development of a Program Quality Framework for Career and Engineering Education Programs: A Researcher-Practitioner Collaborative Project. Society for Research on Educational Effectiveness.

Charyton, C. \& Merrill, J. A. (2009). Assessing general creativity and creative engineering design in first year engineering students. Journal of engineering education, 98(2), 145-156.

Charyton, C., Jagacinski, R. J., Merrill, J. A., Clifton, W., DeDios, S. (2011). Assessing Creativity Specific to Engineering with the Revised Creative Engineering Design Assessment. Journal of Engineering Education, 100, 778-799.

Chen, C. K., Jiang, B. C., \& Hsu, K. Y. (2005). An empirical study of industrial engineering and management curriculum reform in fostering students' creativity. European Journal of Engineering Education 30(2), 191-202. 
Conwell, J. C., Catalano, G. D., \& Beard, J. E. (1993). A case study in creative problem solving in engineering design. Journal of Engineering Education, 82(4), 227-231.

Corebima, A. D., Susilo, H., \& Zubaidah, S. (2017). Creative Thinking of Low Academic Student Undergoing Search Solve Create and Share Learning Integrated with Metacognitive Strategy. International Journal of Instruction, 10(2).

Cropley, D. H. (2016). Creativity in engineering. In Multidisciplinary Contributions to the Science of Creative Thinking. Springer Singapore, 155-173.

Cropley, D. H., \& Cropley, A. J. (2005). Engineering creativity: A systems concept of functional creativity. Creativity across domains: Faces of the muse, 169-185.

Daly, S. R., Mosyjowski, E. A. \& Seifert, C. M. (2014). Teaching creativity in engineering courses. Journal of Engineering Education, 103(3), 417-449.

Fan, B. L. (2017). Theory of Modern Engineering Practice Teaching. DEStech Transactions on Computer Science and Engineering, (itme).

Green, G. (2001). Redefining engineering education: the reflective practice of product design engineering. International Journal of Engineering Education, 17(1), 3-9.

Guilford, J. P. (1950). Creativity. American psychologist, 5(9), 444.

Hatchuel, A., Le Masson, P. \& Weil, B. (2017). CK Theory: Modelling Creative Thinking and Its Impact on Research. In Creativity, Design Thinking and Interdisciplinarity. Springer, Singapore, 169-183.

Hoidn, S. \& Kärkkäinen, K. (2014). Promoting skills for innovation in higher education: A literature review on the effectiveness of problem-based learning and of teaching behaviours. OECD Education Working Papers, (100), 0_1.

Izvorska, D. (2016). A Model for Formation and Development of Students' Technology Competence in Technical Universities. Educational Researcher, 8, 45.

Kansal, N., Solanki, V. K. \& Kansal, V. (2016). Educational Data Mining and Indian Engineering Education System: A Review. Feature Detectors and Motion Detection in Video Processing, 18.

Kazerounian, K. \& Foley, S. (2007). Barriers to creativity in engineering education: A study of instructors and students perceptions. Journal of Mechanical Design, 129(7), 761-768.

Monteiro, F., Leite, C., \& Rocha, C. (2018). From the dominant engineering education perspective to the aim of promoting service to humanity and the common good: the importance of rethinking engineering education. European Journal of Engineering Education, 1-15.

Morse, L. C., Babcock, D. L., \& Murthy, M. (2014). Managing engineering and technology. Pearson. 
Nguyen, L. \& Shanks, G. (2009). A framework for understanding creativity in requirements engineering. Information and software technology, 51(3), 655-662.

Phelan, S. G. (2001). Developing creative competence at work: The reciprocal effects of creative thinking, self-efficacy and organizational culture on creative performance (Doctoral dissertation, ProQuest Information \& Learning).

Reed, L. C. (2011). Creative capabilities in technological design. Purdue University.

Rugarcia, A., Felder, R. M., Woods, D. R., \& Stice, J. E. (2000). The future of engineering education I. A vision for a new century. Chemical Engineering Education, 34(1), 16-25.

Runco, M. A. (2014). Creativity: Theories and themes: Research, development, and practice. Elsevier.

Saorín, J. L., Melian-Díaz, D., Bonnet, A., Carrera, C. C., Meier, C. \& De La TorreCantero, J. (2017). Makerspace teaching-learning environment to enhance creative competence in engineering students. Thinking Skills and Creativity, 23, 188-198.

Savery, J. R. (2015). Overview of problem-based learning: Definitions and distinctions. Essential readings in problem-based learning: Exploring and extending the legacy of Howard S. Barrows, 9, 5-15.

Schoen, J. L., Bowler, J. L. \& Schilpzand, M. C. (2016). Conditional Reasoning Test for Creative Personality: Rationale, Theoretical Development, and Validation. Journal of Management, 0149206315618012.

Si, L., Zhuang, X., Xing, W. \& Guo, W. (2013). The cultivation of scientific data specialists: Development of LIS education oriented to e-science service requirements. Library Hi Tech, 31(4), 700-724.

Walther, J., Kellam, N., Sochacka, N., \& Radcliffe, D. (2011). Engineering competence? An interpretive investigation of engineering students' professional formation. Journal of Engineering Education, 100(4), 703-740.

Wei, X., Weng, D., Liu, Y. \& Wang, Y. (2015). Teaching based on augmented reality for a engineering creative design course. Computers \& Education, 81, 221-234. 